\title{
Liquid Sugar Extraction from Date Palm (Phoenix dactylifera L.) Fruits
}

\section{Gamal A El-Sharnouby ${ }^{1 *}$, Salah M Aleid ${ }^{1,2}$ and Mutlag M Al-Otaibi ${ }^{1}$}

${ }^{1}$ Department of Food and Nutrition Sciences, College of Agricultural and Food Sciences, King Faisal University, Saudi Arabia

${ }^{2}$ Date Palm Research Center of Excellence, King Faisal University, Saudi Arabia

\begin{abstract}
In date syrup manufacturing, date fruits (Phoenix dactylifera L.) are mixed with a suitable amount of water with heating at a temperature greater than $70^{\circ} \mathrm{C}$ for about $1 \mathrm{~h}$. These conditions are not satisfactory for extraction greater amount of liquid sugar (date syrup). In addition, overheating for an extended period could damage nutritious materials and changes product's color. In this study, pectinase/cellulase enzymes and sonication processes were used to achieve maximum syrup extraction from a date variety (Reziz) compared with classical method. The following variables were examined: fruit/water ratio, mixture of enzymes percent and ultrasonic power. Enzymes and Ultrasound were applied for improving the quantity and quality of extracted syrup. Date extract was filtered with filter system (Novox 200, filtrox) which could result entirely a clear syrup and then concentrated by a rotary evaporator until about $75 \%$ total solids to produce higher quality syrup. Physicochemical properties of each collected sample during process were evaluated. Results showed that sonication power $25 \%$ at ratio $1 / 3 \mathrm{D} / \mathrm{W}$ could lead to a higher extraction of RSS (Recovery of Soluble Solids) (74.30\%) in a shorter time with a better physicochemical quality of syrup in comparison to mixture of enzymes $1.0 \%$ $(66.70 \%)$ and classical methods of extraction (58.45\%). Data indicated the possibility of employing ultrasound (25\%) or enzymes processes (pectinase/ cellulase $0.1 \%$ ) for producing greater syrup amount highly desirable for use in food product development.
\end{abstract}

Keywords: Date syrup; Reziz; Enzymes; Ultrasound; Extraction; Liquid sugar

\section{Introduction}

The date palm (Phoenix dactylifera L.) is one of the oldest fruit trees in the Arabian Peninsula and has played an important role in day-to-day life of the people of this region for the last 7000 years [1]. The production of date fruits in the Kingdom of Saudi Arabia reached about 1.07 million tons (annually). The global production of fruit from the date palm tree was estimated at 7.75 million tons worth US $\$ 3.82$ billion in 2010 [2]. Saudi Arabia is ranked as the second largest date producer in the world after Egypt, with an annual production of 1.078 million tons of dates produced from over 24 million date palm trees [3].

The development of date fruits is divided into three stages, Khalal, Rutab and Tamr. Khalal stage dates are immature with hard texture, yellow or red or pink color, Total Soluble Solids (TSS) (A portion of the total solids which are dissolved in the water and pass through a filter prepared by depositing a layer of Kaolin paste into a standard filter paper) of 30-45 brix, astringent and edible; Rutab stage dates soften at the tip of the fruit, RSS of 55-60 ${ }^{\circ} \mathrm{brix}$, free from astringency and edible; Tamr stage dates are fully ripped with RSS of $60-84^{\circ} \mathrm{Brix}$ and edible. Dates are generally harvested at Tamr stage that is after the development of TSS of $60-70^{\circ}$ Brix that are edible at this stage. Date syrup is used in food preparations like sweets, snacks, confectionery, bakery products and health foods. Mature date fruits are also processed into products such as date bars, date syrup, etc. Dates are known to be rich in carbohydrates ( $80 \%)$ but quite low in protein $(2-3 \%)$. Date fruits (Tamr) contained moisture ranged from 10 to $22 \%$, total sugars 62 to $75 \%$, protein 2.2 to $2.7 \%$, fiber 5 to $8 \%$, fat 0.4 to $0.7 \%$, ash 3.5 to $4.2 \%$, total acidity 0.06 to $0.20 \%$, ascorbic acid 30.0 to $50.0 \mathrm{mg} \%$,on dry weight basis. Date fruit as a nutritive product contains sugar substances about (70.6-76.3\%), proteins (1.9-3\%), fat (0.2-2.8\%), minerals $(1.3 \%)$ and vitamins [4]. The flesh of a fully ripe date (Tamr), consist of twothird sugars and one-quarter water, the rest being mainly cellulose, pectin, ash, and vitamins. The date is considered as a nutritious fruit as research has indicated the clear contribution of dates to human health when consumed with other food constituents. Dates contain sufficient quantities of minerals and vitamins that help to prevent deficiency [5]. Dates also have an emerging role of importance as a substitute for refined sugar. In food technology, date syrup as the main and general by-product of date is used for foodstuffs such as jams, marmalades, concentrated beverages, chocolates, ice cream, confectioneries, honey, etc [6-8]. As the Kabkab (Iranian Kabkab Dates) date has a high amount of wastes, it can be used for the date syrup production with economical advantageous [9]. Date syrup (dibs) is probably the most common derived date product. It is produced as an incidental by-product when bagged humid dates are heaped for several months, some syrups extracted by the force of their own weight. In addition, it is produced in the home and village by extraction and boiling down of juice, and on a semi and full industrial scale. As the Reziz date has a high amount of wastes, it can be used for the date syrup production with economical advantageous. In date's syrup industry the fruit are mixed with water and heated for around $1 \mathrm{~h}$ at $70^{\circ} \mathrm{C}$, when the main components, sugars, are extracted. This method destroys some nutritive components and darkens the product's color.

Specific enzymes and enzyme combinations are needed to optimize the extraction of any particular fruit juice about yield and quality. The use of cellulases and pectinases has been an integral part of modern fruit processing technology, involving treatment of fruit mashes as they not only facilitate easy pressing and increase in juice recovery, but also ensure the highest possible quality of products. For example, pectinases can hydrolyze pectin and cause pectin-protein complexes to flocculate, so the resulting juice has a much lower amount of pectin and a lower viscosity, which is advantageous for the filtration process. These enzymes not only help in softening the plant tissue but also lead to the release of cell contents that may be recovered with high yield.

*Corresonding author: Gamal A. El-Sharnouby, Department of Food and Nutrition Sciences, College of Agricultural and Food Sciences, King Faisal University, Saudi Arabia, Tel: 0557786398; E-mail: Gelsharnoby@kfu.edu.sa

Received May 06, 2014; Accepted December 03, 2014; Published December 10,2014

Citation: El-Sharnouby GA, Aleid SM, Al-Otaibi MM (2014) Liquid Sugar Extraction from Date Palm (Phoenix dactylifera L.) Fruits. J Food Process Technol 5: 402. doi:10.4172/2157-7110.1000402

Copyright: () 2014 El-Sharnouby GA, et al. This is an open-access article distributed under the terms of the Creative Commons Attribution License, which permits unrestricted use, distribution, and reproduction in any medium, provided the original author and source are credited. 
Pectinases also used in sugar extraction process from date fruits. These enzymes break down complex polysaccharides of plant tissues into simpler molecules like galacturonic acids. Enzymes can be used economically if proper strategies are used for their optimization during clarification of fruit pulp.

A number of papers have dealt with the ultrasonically assisted extraction of different materials. High efficiency and shortening of extraction time are the main positive effects of such extractions. The most important proposed mechanism for these behaviors is the intensification of mass transfer and easier access of the solvent to the content of the cell. In addition, the collapse of cavity near the cell wall can lead to cell disruption and releases the cell contents into the extraction medium [10]. Ultrasound can also inactivate a range of microorganisms. Ultrasound in the range of $20-100 \mathrm{kHz}$ frequency is mainly used in industrial processes and that those with higher frequency are mainly used for detection and analyses [11-13].

This present work focuses on the suitability of date extract (Syrup) as an alternative sweetener ingredient to replace expensive and imported sucrose in many food industries such as Candy, bakery products and soft drinks. In addition, the comparison of conventional, enzymes (pectinase and cellulase) and ultrasonically assisted extraction methods of liquid sugar from Reziz fruits to use in food product development.

\section{Materials and Methods}

\section{Materials}

Date fruits: Date fruits (Phoenix dactylifera L.) at the tamr stage of maturity, i.e. Reziz, obtained from Al-Hassa Govemorate, Date Factory, Kingdom of Saudi Arabia were used in this work.

Date khalas syrup: Date syrup of Khalas variety at TSS (78\%) was obtained from local market in Alhassa and used as control Sample for sensory evaluation.

Enzymes: Pectinase and cellulase enzymes: (in liquid state) were provided from Sigma company (USA) in form of aqueous solution. Activity of pectinase ( $\geq 3,800$ units $/ \mathrm{mL}$ ) and cellulase ( $\geq 1000$ units $/ \mathrm{g}$ ).

Ultrasound device: ÔMisonix' model XL-2020, 20 kHz, 500 W, horn type machine with $12.7 \mathrm{~mm}$ tip diameter.

Filtration system: Filtration system (Novox 200, filtrox, Swiss) for fine purification was used.

Chemicals: All chemicals and solvents were obtained from SigmaAldrich Co. (Dorset, UK), unless otherwise specified.

\section{Methods}

The date fruits were pitted and sliced to pieces with the approximate dimensions of $1 \mathrm{~cm} \times 1 \mathrm{~cm} \times 0.3 \mathrm{~cm}$. Then the prepared date fruits were used for three extraction methods.

Extraction of date syrup with water: Date pulp (100 gm) in a typical expermints put in an erlenmeyer flask $(1 \mathrm{~L})$ and water were added at different ratios. The date pulp/water ratios $(\mathrm{D} / \mathrm{W})$ were $1: 2$, 1:3, 1:4 and 1:5 and samples were blending using a hand-held blender (Phillips, Holland). The $\mathrm{pH}$ was adjusted to $6.0 \pm 0.2$. Each sample, in triplicate, was placed in water bath at $70^{\circ} \mathrm{C}$ for $2 \mathrm{~h}$. After heating the slurry was filtered through a cheese cloth with a hand press to remove large impurities and insoluble matters, then centrifuged (model RC 28 $\mathrm{S}$, USA) at $8000 \mathrm{~g}$ for $10 \mathrm{~min}$, and the supernatant was decanted and weighed.
Extraction of date syrup with pectinase/cellulase enzymes enzymes: The extraction procedure was also repeated at chosen ratio $(1 / 3 \mathrm{D} / \mathrm{W})$ with addition of enzymes mixture. Samples were blending using a hand-held blender (Phillips, Holland), then pectinase and cellulase preparation (1:1) at the rate of $0.25,0.50$ and $1.0 \%(\mathrm{v} / \mathrm{w})$ were added and $\mathrm{pH}$ was adjusted to $6.0 \pm 0.2$ before the addition of enzyme preparations. Each sample, in triplicate, was placed in an water bath at $50^{\circ} \mathrm{C}$ for $4 \mathrm{~h}$. Then the slurry was filtered through a cheese cloth with a hand press to remove large impurities and insoluble matters. They were then centrifuged and the supernatant was decanted and weighed.

Extraction of the date syrup with ultrasonic waves: The extraction procedure was also repeated at ratio 1:3 W/D ratio with using ultrasonic device (Hielscher, Model UP400S, $400 \mathrm{~W}$, with $14 \mathrm{~mm}$ tip diameter, Germany) at different power of ultrasonic device $(15,20$ and 25\%). After blinding, each sample, in triplicate, was placed in an Erlenmeyer flask $(1 \mathrm{~L})$, and water bath at $40^{\circ} \mathrm{C}$ for $2 \mathrm{~h}$ and performed to ultrasonic for $60 \mathrm{~min}$. as described by. Then the slurry was filtered through a cheese cloth with a hand press to remove large impurities and insoluble matters. They were then centrifuged and the supernatant was decanted and weighed.

Filtration method: Finelly, the obtained extract from different extraction methods was filtered in Filter system (Filtrox AG, CH 9000 St. Gallen, Switzerland) with an effective clarifying filtration area of $1.02 \mathrm{~m}^{2}$ and $2.0 \mu \mathrm{m}$ pore size, operated at a pressure of $1 \mathrm{bar}$ for fine purification. The clear extract was concentrated to about $78^{\circ}$ Brix using rotary evaporator (Rotavapor R-124, Buchi, Switzerland) at 70. The concentrated samples were packed in sealed glass bottles and stored at room temperature $\left(20^{\circ} \mathrm{C}\right)$ until analyzed and evaluated.

Chemical and physical analyses: The date fruit samples were evaluated for moisture, ash, protein and pectin contents (as Ca pectate) and acidity (as citric acid) using standard methods [14]. Potassium and sodium were determined using Flame photometer. Calcium, magnesium and iron were detennined using Atomic absorption Spectrophotometer 2380 as described in [14].

(TSS \%): Total soluble solids (TSS \%) with main component of sugar in date's syrup were performed by Brix refractometry using the Abbé refractometer (Milton Roy, USA) as Entezari et al.,.

(RSS \%) : the recovery of soluble solids (RSS \%) was computed as described by Al-Hooti et al. as follows:

$$
\mathbf{R S S}=\frac{\text { Weight of extract } \times \% \text { TSS of extract }}{\text { Weight ofdate pulp taken }} \times 100
$$

Sugars: The identification and quantificatin of Sugars (glucose, fructose and sucrose was conducted using HPLC (Agilent Technologies, 1260 Model Infinity,USA) with refractive index detection as described by [15]. The separation was carried out using a purospher star NH2 column $(4.6 \in 250 \mathrm{~mm} \in 5 \mu \mathrm{m}$, Merck, Germany). The color of the diluted date syrup was measured as optical density (O.D) at $520 \mathrm{~nm}$ using a spectrophotometer (Shimadzu, Model UV-1800, Jpan). pH was determined by $\mathrm{pH}$ meter (Jenway, Model 3520, UK) [16].

Sensory evaluation of date syrup: The sensory characteristics of date syrups were conducted to determine the acceptapility of the product. Surup samples were presented in a sealed pouch coded with different numbers to six panalists of staff members at King Faisal University, Saudi Arabia, who were asked to rate each sensory attribute. Date surups samples were evaluated. Syrup samples were evaluated for color, taste, texture and overall quality on a 9-point hedonic scale [17]. However, evaluated date syrup was compared with the sugar cane 
syrup (Black Honey) from the local market (Alahsa -Saudi Arabia).

Statistical analysis: Results were given as means \pm standard deviation of three independent determinations $(n=3)$. One way analysis of variance (ANOVA) was used to test of significancecomparison between means were tasted by Duncan's multiple range test. Differences were considered to be significant at $\mathrm{p}<0.05$ according to [18]. All statistical analyses were performed using SAS (9.3) [19].

\section{Results and Discussions}

\section{Chemical and physical evaluation of Reziz date}

The data of gross chemical composition are shown in Figure 1. It could be concluded that date samples contained predominant amount of sugars and moderate levels of crude protein and ash. Reziz date variety recorded a higher amount of sugars (79\%), Moisture (11\%) crude protein $(2 \%)$, crude fat $(2 \%)$, ash $(3 \%)$ and pectin $(2.5 \%)$. However, it was clear from the obtained data that the moisture content of dates was less than the recorded average of semi-dry varieties (15\%). This might be reasoned to a higher loss in moisture content after harvesting during storage and marketing.

\section{Extraction of Reziz date syrup}

Date syrup is a popular commodity produced by some date processing plants in Saudi Arabia. Moreover, considerable amounts of date syrup are produces at homes from local date varieties. Dates grown in Saudi Arabia and their sugar content should justify their use as a source of liquid sugar sautés to many food industries. Date syrups are composed of large amounts of reducing sugars. Fructose and glucose are the major sugar fractions in date syrup.

The effect of date pulp / water (D/W) ratio on the sugar extraction rate (RSS \%) of date syrup was presented in (Figure 2) The data revealed that, increasing the $\mathrm{D} / \mathrm{W}$ ratio up to $1 / 3$ increased the RSS \%. This positive relationship could be due to the increased rate of molecular diffusion, reduced liquid viscosity and better liquid solid contact. Also, it is evident from data that, RSS \% was relatively affected by the moisture content of date pulp, whereas, date fruits (at ratio $1 / 3 \mathrm{D} / \mathrm{W}$ ) recorded the highest RSS \% (58.45\%) compared with lowest ratio 1/1 $\mathrm{D} / \mathrm{W}(52.55 \%)$. The water to date ratio was evidently a very important parameter in solids extraction, for technical and economic reasons. A high ratio will assist rapid and thorough extraction. The low RSS \% of the extract is not easy to preserve on the industrial scale and will require very high energy to concentrate. At low $\mathrm{D} / \mathrm{W}$ ratio will leave much of the unextracted soluble solids. The extraction of date syrup from dates usually gives a yield of $60 \%$. It usually extracted by means of pressure or heat extraction (with 2.5 times their weight water), followed by filter press. Thus, this ratio $(1 / 3 \mathrm{D} / \mathrm{W})$ was chosen in further experimental.

\section{Date syrup evaluation}

Data concerning the physical characteristics of date syrup presented in Table 1. The total soluble solids (TSS \%) and refractive index of the date syrup were higher ( $84.45 \%$ and 1.4885 respectively). This is principle due to the high level of sugars and relatively low moisture content. The $\mathrm{pH}$ value recorded 4.91 for date syrups. The optical density of $20 \%$ TSS of date syrups at $520 \mathrm{~nm}$ was 0.56 . The data showed that, the prepared date syrup had high acidity $0.69 \%$ (as citric acid), therefore the expected storage ability will be high.

Effect of pectinase/cellulose enzyme preparations $(\mathrm{ml} / 100 \mathrm{~g})$ and ultrasonic process on the Recovery of Soluble Solids (RSS \%) at ratio $1 / 3 \mathrm{D} / \mathrm{W}$ from Reziz date is shown in Table 2. Three treatments of pectinase / cellulose enzyme preparations used namely, 0.50, 0.75 and $1.0(\mathrm{ml} / 100 \mathrm{~g}$ pulp date) as well as three treatments of ultrasound power $(15,20$ and $25 \%)$ have been used for increasing the yield of syrup from fruits pulp at ratio $1 / 3 \mathrm{D} / \mathrm{W}$. By using these methods of extraction the extraction yield of soluble solids for Reziz date variety was enhanced. However, The addition of enzyme preparations, even at the level of $1.0 \%$, was found to increase the extraction yield of soluble solids from 62.40 to $66.70 \%$. As the extraction yields of soluble solids from date pulps increased, this may open up the avenue for the use of such enzyme preparations for date fruit pulp processing for the development of sucrose substitutes based on date fruits. This causes considerable loss of soluble solids and the percentage of broken segments is also high. When pectinolytic enzymes are used deskinning is completed within 90 to 120 minutes. Pectinases are also used in sugar extraction process from date fruits. However, The use of sonication power at $25 \%$ was significantly different than the 15 and $20 \%$ level, so the use of $25 \%$ sonication power was found to be optimal for the maximum extraction yields of soluble solids from date fruit pulps.

The effect of different treatments (at ratio $1 / 3 \mathrm{D} / \mathrm{W}$ ) on sugars content is shwon in Figure 3 and Table 3. From such data, it was observed that the sugars content of date syrup samples arranged between 81.88 and $83.56 \%$. However, ultrasound tratments resulted in increses in sugar content followed by enzymes treatments ( 83.56 and $82.85 \%$, respectively). Meanwhile, the effect of different treatments (at ratio $1 / 3 \mathrm{D} / \mathrm{W}$ ) on chemical composition of date syrup is shown in Table 3. The moisture content of date syrup samples was $17.20-18.50 \%$, protein content was $1.16-1.22 \%$, fat was $2.04-2.22 \%$ and ash ranged

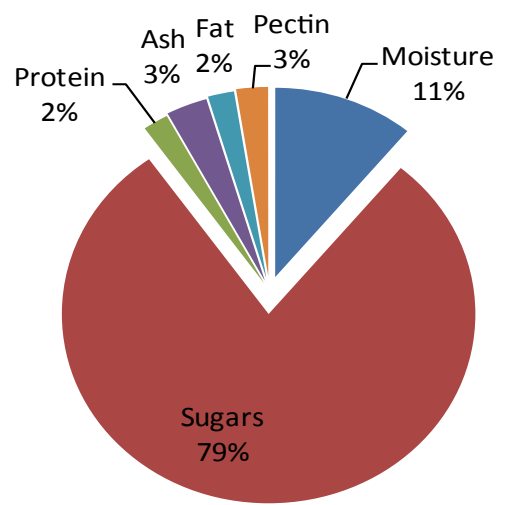

Figure 1: Chemical Composition of Riziz Date Fruits

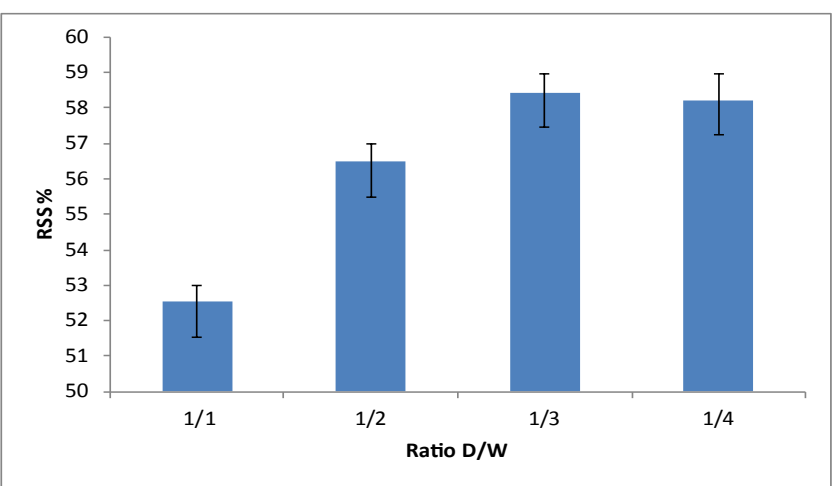

Figure 2: Effect of date / water ratio (D/W) on the extraction yield (RSS \%) of soluble solids from Reziz date fruit. 


\begin{tabular}{|c|c|c|c|c|c|c|c|}
\hline Date Syrup & TSS (\%) & \multicolumn{2}{|c|}{ Sugars $\%$} & Refractive index & Acidity \% & pH & Color O.D \\
\hline Reziz Syrup & 84.25 & 81.8 & & 1.4885 & 0.69 & 4.91 & 0.56 \\
\hline \multicolumn{8}{|c|}{ Table 1: Characteristics of date syrup (at ratio $1 / 3 \mathrm{D} / \mathrm{W}$ ) } \\
\hline \multirow{2}{*}{\multicolumn{3}{|c|}{ Extraction yield RSS \% }} & \multicolumn{5}{|c|}{$\begin{array}{l}\text { Concentration }(\mathrm{ml} / 100 \mathrm{~g}) \text { of pectinase and cellulose } \\
\text { enzyme }\end{array}$} \\
\hline & & & 0.50 & 0.75 & 1.0 & & \\
\hline \multirow{2}{*}{\multicolumn{2}{|c|}{ RSS $^{* *}$}} & & 62.40 & 64.40 & 66.70 & & \\
\hline & & & \multicolumn{5}{|c|}{ Sonication Power } \\
\hline \multicolumn{3}{|l|}{ Power setup } & \multicolumn{2}{|c|}{\begin{tabular}{l|l}
$15 \%$ & $20 \%$
\end{tabular}} & \multicolumn{3}{|l|}{$25 \%$} \\
\hline \multicolumn{3}{|l|}{ RSS** } & \multicolumn{2}{|l|}{68.35} & \multicolumn{3}{|l|}{74.30} \\
\hline
\end{tabular}

** Recovery of soluble solids

Table 2: Effect of pectinase/cellulose enzyme preparations $(\mathrm{ml} / 100 \mathrm{~g})$ and Sonication Power on the extraction yield (RSS \%) at ratio (1/3 D/W) of soluble solids from Reziz date

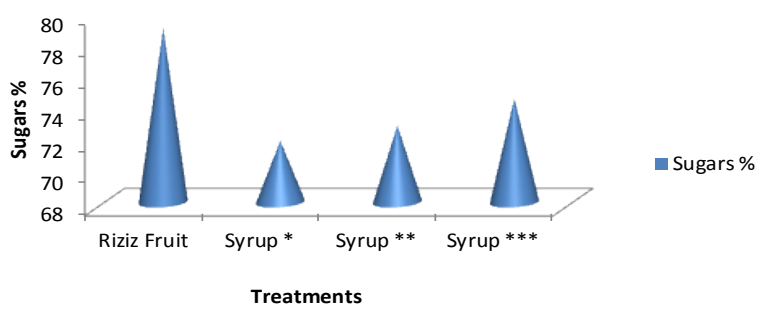

* Date Syrup control ** Date Syrup with enzymes $1.0 \% * *$ Date Syrup...

Figure 3: Effect of date / water ratio (D/W) on the extraction Sugars \% from Reziz date fruit

\begin{tabular}{|c|c|c|c|c|c|c|}
\hline Samples & Moisture & Sugars & protein & Fat & Ash & Pectin \\
\hline $1^{*}$ & 18.50 & 81.88 & 1.16 & 2.04 & 1.82 & 0.00 \\
\hline $2^{* *}$ & 17.50 & 82.85 & 1.22 & 2.22 & 1.06 & 0.00 \\
\hline $3^{* * *}$ & 17.20 & 83.56 & 1.20 & 2.20 & 1.08 & 0.00 \\
\hline
\end{tabular}

${ }^{*}$ Date Syrup ** Date Syrup with enzymes 1.0\% *** Date Syrup with Sonication $25 \%$ Table 3: Effect of pectinase/cellulase $(1.0 \mathrm{ml} / 100 \mathrm{~g})$ and Sonication Power $25 \%$ on chemical composition $\%$ of date syrup, on dry weight basis (at ratio 1:3 D/W)

between $1.08-1.82 \%$. On the contrary, pectin content not detected in date syrup samples. This is due to the impact of using of enzymes mixture and filter system (Novox 200, filtrox) which could result entirely a clear juice.

Minerals composition of concentrated date syrup prepared from Reziz pulp date (at ratio $1 / 3 \mathrm{D} / \mathrm{W}$ ) were tabulated in Table 4 . Date syrups are good source of minerals. However, the mineral composition of date syrup shows high amount of $\mathrm{K}$, fair amount of $\mathrm{Na}$ and low amounts of $\mathrm{Ca}$, and $\mathrm{Mg}$ as well as trace amounts of $\mathrm{Fe}$ and $\mathrm{Mn}$. Ultrasound tratments resulted in increses in minerals content followed by enzymes treatments. It could be concluded from the obtained results that, the slight amounts of minerals content were found after addition of enzymes mixture and using of ultsound process. This is due to the effect of enzyme mixture and destroying effect of ultrasound waves on date cell and more extraction of total soluble solids take place and the fact that elements content increased after drying as a result of concentration effect. Also, the different in element contents during different drying methods is due to the differences in moisture content of samples.

Physico-chemical compositions of concentrated date syrups before and after treatments with addition of pectinase/cellulose enzyme and ultrasound process have been presented in Table 5. Clear increase was observed in TSS \% (83.25 to $86.00 \%)$, slight increase in acidity $(0.69$ to $0.72 \%$ ), and slight decrease in $\mathrm{pH}$ (4.91 to 4.83 ) while the treatable acidity (expressed as percentage citric acid) was increased from 0.69 to $0.72 \%$. However, sugas content (glucose, fructose and sucrose) were analysed by HPLC apparatus as mentioned in materials and methods. The date syrup had $81.88 \%$ total sugars on dry weight basis (36\% fructose, $34.50 \%$ glucose and $1.33 \%$ sucrose), and $83.25 \%$ total solids on dry weight basis. However, it is clear that fructose and glucose are the major fractions of sugars. It can be reported that Reziz date syrups contains about equal amount of glucose and fructose $(36.00$ $34.50 \%),(37.05,34.60 \%)$ and $(38.23,35.33 \%)$ for date syrup, syrup with enzymes mixture (1.0\%) and syrup with sonication $25 \%$, respectively. Date syrups contained more fructose than glucose. In general, Saudi dates varieties contain about $70 \%$ reducing sugars with almost equal quantities of glucose and fructose.

\section{Organoleptic evaluation of date syrups}

The prepared date syrups were palatability tested in terms of color, taste, consistency, and acceptability compared with date syrup from local market as control. The results are listed in Table 6 , it was evident from these data that, syrup prepared at $25 \%$ of sonication power recorded the highest average scores for color, texture, taste, flavor and overall acceptability followed by syrup of $1.0 \%$ pectinase and cellulose enzyme mixture and date syrup $(1 / 3 \mathrm{D} / \mathrm{W})$. From the same data, it was clear that, the control syrup (from local market) recorded the lowest scores of all sensory evaluation terms. On the other hand, there were significant differences among all date syrups and control syrup in their organoleptic properties. The results stated that, prepared date syrups by sonication $25 \%$ followed by pectinase and cellulose enzyme are highly desirable and more acceptable.

\section{Conclusion}

The research data presented here indicate a strong possibility of producing concentrated date syrup for use in product development. Riziz date variety was found to be high in total sugar contents (about 83\%). Among the various extraction procedures employed for producing date syrup, the use of date pulp to water ratio $(\mathrm{D} / \mathrm{W}$ $1 / 3$ ) with ultrasonic process at power $25 \%$ gave the highest recovery of total soluble solids $(74.30 \%)$ compared with pectinase/cellulase enzymes at $1.0 \%(66.70 \%)$ and syrup control (58.45\%). Reziz date syrups contains almost equal amount of glucose and fructose during different treatments. Glucose and fructose were the major sugars present in date syrup. The date syrup was found to be a good source of macro-elements like calcium, phosphorus, potassium, magnesium, but

\begin{tabular}{|l|c|c|c|c|c|c|c|c|c|}
\hline \multirow{2}{*}{ Date Syrup } & \multicolumn{4}{|c|}{ Macro-elements } & \multicolumn{4}{c|}{ Micro-elements } \\
\cline { 2 - 11 } & $\mathbf{C a}$ & $\mathbf{P}$ & $\mathbf{N a}$ & $\mathbf{K}$ & $\mathbf{M g}$ & $\mathbf{F e}$ & $\mathbf{Z n}$ & $\mathbf{C u}$ & $\mathbf{M n}$ \\
\hline Reziz fruits & 72.30 & 166.13 & 655.70 & 960.80 & 49.70 & 0.93 & 0.71 & 0.82 & 0.36 \\
\hline 1* $^{*}$ & 66.30 & 168.21 & 630.51 & 949.21 & 42.13 & 1.00 & 0.66 & 0.62 & 0.22 \\
\hline $2^{* *}$ & 71.50 & 170.20 & 650.20 & 960.30 & 45.20 & 1.10 & 0.70 & 0.70 & 0.25 \\
\hline $3^{* * *}$ & 73.40 & 173.15 & 668.70 & 983.70 & 53.20 & 0.13 & 0.75 & 0.78 & 0.32 \\
\hline
\end{tabular}

${ }^{*}$ Date Syrup ** Date Syrup with enzymes $1.0 \%$ *** Date Syrup with Sonication $25 \%$ Table 4: Effect of pectinase/cellulase and Sonication Power on Mineral composition of date syrup, on dry basis (at ratio $1 / 3 \mathrm{D} / \mathrm{W}$, on dry basis)

\begin{tabular}{|l|l|l|l|l|l|l|l|}
\hline Date Syrup & $\begin{array}{l}\text { TSS } \\
\%\end{array}$ & $\mathbf{p H}$ & $\begin{array}{l}\text { Acidity } \\
\%\end{array}$ & $\begin{array}{l}\text { Sugars } \\
\%\end{array}$ & $\begin{array}{l}\text { Fructose } \\
\%\end{array}$ & $\begin{array}{l}\text { Glucose } \\
\%\end{array}$ & $\begin{array}{l}\text { Sucrose } \\
\%\end{array}$ \\
\hline $\mathbf{1}^{*}$ & 83.25 & 4.91 & 0.69 & 81.88 & 36.00 & 34.50 & 1.33 \\
\hline $\mathbf{2}^{* *}$ & 84.16 & 4.85 & 0.72 & 82.85 & 37.05 & 34.60 & 1.20 \\
\hline $\mathbf{3}^{* * *}$ & 86.00 & 4.83 & 0.72 & 83.56 & 38.23 & 35.33 & 1.00 \\
\hline
\end{tabular}

*Date Syrup ** Date Syrup with enzymes $1.0 \%$ *** Date Syrup with Sonication $25 \%$ Table 5: Effect of pectinase/cellulase and Sonication Power on Physicochemical composition of concentrated date syrup (at ratio $1 / 3 \mathrm{D} / \mathrm{W}$, on dry basis) 
Citation: El-Sharnouby GA, Aleid SM, Al-Otaibi MM (2014) Liquid Sugar Extraction from Date Palm (Phoenix dactylifera L.) Fruits. J Food Process Technol 5: 402. doi:10.4172/2157-7110.1000402

Page 5 of 5

\begin{tabular}{|c|c|c|c|c|}
\hline Syrup & Color & Texture & Taste & Overall quality \\
\hline $1^{*}$ & $7.78 \pm 0.43^{\mathrm{c}}$ & $7.56 \pm 0.51^{\mathrm{b}}$ & $7.53 \pm 0.55^{\mathrm{c}}$ & $7.39 \pm 0.53^{\mathrm{c}}$ \\
\hline $2^{* *}$ & $8.25 \pm 0.60^{\mathrm{b}}$ & $8.28 \pm 0.43^{\mathrm{a}}$ & $8.28 \pm 0.39^{\mathrm{b}}$ & $8.28 \pm 0.43^{\mathrm{b}}$ \\
\hline $3^{* * *}$ & $8.64 \pm 0.38^{\mathrm{a}}$ & $8.53 \pm 0.32^{\mathrm{a}}$ & $8.64 \pm 0.33^{\mathrm{a}}$ & $7.89 \pm 0.21^{\mathrm{b}}$ \\
\hline Khalas control & $7.06 \pm 0.34^{\mathrm{d}}$ & $6.78 \pm 0.39^{\mathrm{c}}$ & $6.69 \pm 0.39^{\mathrm{d}}$ & $6.56 \pm 0.34^{\mathrm{a}}$ \\
\hline
\end{tabular}

Within same column, means with the same letter are not significantly different

*Date Syrup ** Date Syrup with enzymes 1.0\% *** Date Syrup with Sonication $25 \%$

Table 6: Analysis of variance for organoleptic evaluation of date syrup (at ratio $1 / 3 \mathrm{D} / \mathrm{W}$ )

significantly low in sodium. The composition and sensory evaluation of Reziz date syrups confirmed that, it was rich in sugar, minerals and high acceptability. It can be concluded that there is good potential and a possibility to produce syrup from date fruits for use as a replacement of sucrose in food products. Further studies are suggested for the use of these ultrasonic and enzymes process for the production of syrup from date fruits at different temperature and times.

\section{Acknowledgment}

The investigators acknowledge gratefully the financial support from the Deanship of Scientific Research, King Faisal University, Saudi Arabia, material and moral support for this project.

\section{References}

1. Ahmed A, Ahmed AW, Robinson RK (1995) Chemical composition of date varieties as influenced by the stage of ripening. Food Chem 5: 305-309.

2. FAO (2012) Agriculture Data: FAOSTAT.

3. Ministry of Agriculture (2011) Ministry of Agriculture of Saudi Arabia. Indicators about Date industry in Saudi Arabia.

4. Lambiote B (1982) Some aspects of the role of dates in human nutrition. Proceeding of the First International Symposium on Date palm. King Faisal University, Saudi Arabia.

5. Al-Farsi M, Al-Asalvar C, Al-Abid M, Al-Shoaily K, Al-Amry M (2007) Compositional and functional characteristics of dates, syrups, and their byproducts. Food Chem 104: 943-947.

6. El-Sharnouby GA, AL-Eid SM, Al-Otibi MM (2009) Utilization of enzymes in the production of liquid sugar from dates. African Journal of Biochemistry Research 3: 41-47.

7. Al-Hooti SN, Sidhu JS, Al-Saqer MN, Al-Othman JM (2002) Chemical composition and quality of date syrup as effected by pectinase/cellulase enzyme treatment. Food Chem 79: 215-220.
8. Bahramian S, Azin M, Chamani M, Gerami A (2011) Optimization of Enzymatic Extraction of Sugars from Kabkab Date Fruit. Middle-East Journal of Scientific Research 7: 211-216.

9. Taper AR, Jain RK (2014) Pectinases: Enzymes for fruit processing industry. International Food Research Journal 21: 447- 453.

10. Entezari MH, Hagh Nazary S, Haddad Khodaparast MH (2004) The direct effect of ultrasound on the extraction of date syrup and its micro-organisms. Ultrason Sonochem 11: 379-384.

11. Vaillant F, Millan A, Dornier M, Decloux M, Reynes M (2001) Strategy for economical optimisation of the clarification of puply fruit guices using cross flow microfiltration. Journal of Food Engineering 48: 83-90.

12. Mason T, Zhao Y (1994) Enhanced extraction of Tea solids. Ultrasounics 32: 375-377.

13. Vinatoru M (2001) An overview of the ultrasonically assisted extraction of bioactive principles from herbs. Ultrason Sonochem 8: 303-313.

14. AOAC (2000) Official methods of analysis. Washington, DC: Association of Official Analytical Chemists, Methods 37.1.12, 44.1.05, 2.4.03, 37.1.51, 37.1.34.

15. Yang C, Ling X, Zhang C, Shao W (2008) The isolation and characterization of polysaccarides from longan pulp. Separation and Purification Technology 63: 226-230.

16. Salman M, Alghamdi M, Bazaid A, Abdel- Hameed S (2011) Determination of Fructose, Glucose and Sucrose in Taif Grape using High Performance Liquid Chromatography and analysis of mineral salts. Archives of Applied Science Research 3: 488-496.

17. Hoda S, Jood S (2005) Organoleptic and nutritional evaluation of whea biscuits supplemented with untreated and treated fenugreek flour. Food Chemistry 90: 427-435

18. Steel R, Torrie J, Dickey D (1996) Principles and Procedures of Statistics: A Biometrical Approach. McGraw-Hill Higher Education.

19. SAS (2007) Statistical analysis system. User manual SAS/STAT 9.3 second edition. SAS institute Inc., NC, USA. 